\title{
Sekuens Gen Protein Kapsid Mayor L1 Human Papilomavirus 16 dari Isolat Klinik Asal Bandung
}

\author{
Anandayu Pradita, ${ }^{1}$ Edhyana Sahiratmadja, ${ }^{2}$ Sony Suhandono, ${ }^{1}$ Herman Susanto ${ }^{3}$ \\ ${ }^{1}$ Sekolah Ilmu dan Teknologi Hayati, Institut Teknologi Bandung, ${ }^{2}$ Departemen Biokimia Fakultas \\ Kedokteran Universitas Padjadjaran Bandung, ${ }^{3}$ Departemen Obstetri dan Ginekologi \\ Fakultas Kedokteran Universitas Padjadjaran/Rumah Sakit Dr. Hasan Sadikin Bandung
}

\begin{abstract}
Abstrak
Kanker serviks disebabkan oleh infeksi kronik human papillomavirus (HPV) dengan genotipe HPV-16 sebagai HPV tersering yang menginfeksi epitel serviks. Protein penyelubung virus yang disebut kapsid mayor (L1) mempunyai peranan penting dalam menginfeksi epitel serviks. Tujuan penelitian untuk mengisolasi dan menganalisis sekuens gen $L 1 H P V-16$. Pengetahuan mengenai sekuens gen $L 1$ dapat memberikan informasi yang berguna, salah satunya yaitu untuk pengembangan vaksin. Pada studi ini, deoxyribonucleic acid (DNA) virus diekstraksi dari sediaan biopsi pasien kanker serviks yang diambil pada bulan Juni sampai Oktober 2010 di Kebidanan dan Kandungan RS Dr. Hasan Sadikin Bandung. Gen diamplifikasi dengan polymerase chain reaction menggunakan primer spesifik. Infeksi HPV-16 pada jaringan kanker dikonfirmasi dengan menggunakan kit komersial untuk tes genotipe HPV. Fragmen L1 kemudian diklon dan diinsersikan ke dalam pJET1.2/L1-16, kemudian dipotong dengan enzim BamHI dan BgIII untuk kemudian divalidasi dan disekuensing. Hasil sekuensing menunjukkan amplikon gen LI $H P V-16$ sebesar 1.595 pasang basa. Analisis dari dua amplikon gen $L 1$ HPV-16 menggunakan software BIOEDIT dan Basic Local Alignment Search Tool menunjukkan kesamaan ho mologi 99\% dan 97\% dengan sekuens L1 HPV-16 asal Thailand yang terregistrasi pada GenBank. Simpulan, telah dilakukan kloning sekuens gen $L 1$ HPV16 dari dua isolat klinik Bandung. Hasil kloning HPV-16 pada penelitian ini memberikan informasi tentang variasi sekuens yang perlu dipertimbangkan bagi pengembangan vaksin terutama bagi daerah spesifik seperti penduduk asal Indonesia. [MKB. 2014;46(3):143-49]
\end{abstract}

Kata kunci: Human papillomavirus, kanker serviks, gen L1 HPV-16

\section{Sequence of Human Papilomavirus 16 Major Capsid L1 Gene from Clinical Isolates in Bandung}

\begin{abstract}
Cervical cancer is strongly associated with chronic human papillomavirus (HPV) infection. HPV-16 is the most prevalent genotype infecting cervical epithelium. The major coat protein of viral particle (L1) plays a key role in the infection process. Our study aimed to isolate the HPV-16 L1 gene and analyze its sequence. Samples used were samples collected from the Department of Obstetrics and Gynaecology, Dr. Hasan Sadikin General Hospital, Bandung during the period of June to October 2010. In this study, the HPV-16 L1 sequence was analyzed from the viral deoxyribonucleic acid (DNA) extracted from biopsy sample of cervical cancer patient biopsy samples. The HPV-16 L1 amplification was performed using the polymerase chain reaction with specific primer. The HPV infection in the cervical tissue was confirmed by commercial HPV genotyping test. The L1 fragment was cloned into plasmid and the insert of the recombinant clone pJET1.2/L1-16 was digested using BamHI and BgIII. The amplicon result showed HPV-16 L1 gene with a length of 1.595 base pairs. The sequence analysis of two samples using software BIOEDIT dan Basic Local Alignment Search Tool revealed a high level of sequence similarity to L1 HPV-16 from Thailand (99\% and 97\%) as registered in GenBank. In conclusion, the L1 HPV-16 gene from Bandung isolates revealed variations from published sequence. Knowledge on L1 gene sequence may give additional information to the development of vaccine. Further study on vaccine development is currently ongoing using this HPV-16 clone that may be specific to Indonesian population. [MKB. 2014;46(3):143-49]
\end{abstract}

Key words: Cervical cancer, human papillomavirus, L1 HPV-16

Korespondensi: Edhyana Sahiratmadja, dr., Ph.D, Departemen Biokimia Fakultas Kedokteran Universitas Padjadjaran, Jalan Raya Sumedang km 121, Jatinangor Bandung, mobile 0816996309, e-mail e.sahiratmadja@gmail.com 


\section{Pendahuluan}

Kanker serviks merupakan masalah kesehatan perempuan yang perlu mendapatkan perhatian serius. International Agency for Research on Cancer (IARC) telah memperkirakan pada tahun 2050 populasi perempuan usia 15 tahun ke atas yang menderita kanker serviks di seluruh dunia mencapai tiga miliar. ${ }^{1}$ Tingginya kasus kanker serviks berhubungan dengan minimnya akses terhadap fasilitas kesehatan dan juga terbatasnya pengetahuan tentang faktor risiko, pencegahan, deteksi dini, dan terapi terhadap lesi prakanker serviks. ${ }^{2}$ Kanker serviks yaitu kanker nomor dua di Indonesia yang paling umum dengan sekitar 150.000 kasus kanker serviks baru per tahun dan 7.500 kasus di antaranya berakhir dengan kematian. $^{3}$

Human papillomavirus (HPV) merupakan agen infeksius penyebab kanker serviks. Skrining dan vaksinasi merupakan metode yang paling efektif dan tidak dapat dipisahkan satu sama lain sebagai upaya untuk mengontrol kasus kanker serviks. ${ }^{4}$ Skrining tersebut merupakan suatu upaya untuk mendapat informasi tentang distribusinya virus HPV, sedangkan vaksin HPV digunakan untuk mengontrol transmisi penyakit seksual melalui infeksi HPV dengan genotipe highrisk atau ganas. ${ }^{4}$ Genom virus ini terdiri atas DNA beruntai ganda sebesar 7.200-8.000 bp. Genom fungsional dibagi menjadi tiga wilayah. Daerah pertama yaitu daerah noncoding (regulasi hulu) sebesar 400-1.000 bp yang disebut juga dengan long control region (LCR). Daerah kedua adalah daerah wilayah awal yang terdiri atas early protein open reading frame (ORF) yaitu E1, E2, E4, E5, E6, dan E7. Gen E1 dan E2 memungkinkan transkripsi dan replikasi virus, gen $E 1, E 2$, dan $E 4$ berperan dalam pelepasan virus baru yang dibentuk dari pengelupasan sel epitel, sedangkan gen E6 dan E7 bertanggung jawab untuk karakteristik transformasi virus yang bersifat onkogenik. Daerah ketiga adalah daerah wilayah akhir late protein yang mengkode protein L1 dan L2 untuk pembentukan kapsid virus atau amplop virus. Kapsid L1 dan L2 berkontribusi terhadap penularan HPV. ${ }^{5}$

Major late protein $\mathrm{L} 1$ atau protein kapsid mayor L1 merupakan suatu protein yang terdapat pada kapsid selubung virus. ${ }^{5}$ Amplop virus ini tersusun atas 360 protein kapsid mayor L1 yang diatur dalam 72 subunit identik dikenal sebagai pentamer atau kapsomer, dan protein kapsid minor L2 yang terletak di pusat kapsomer. Pentamer L1 dapat diekspresikan dalam suatu sistem yang menyelubungi virus dan juga membentuk partikel yang mirip dengan virus (virus-like particles, VLPs). VLP telah digunakan dalam mendesain vaksin. ${ }^{6}$ Pemberian vaksin HPV berbentuk VLP ini dapat meningkatkan titer antibodi, sehingga tubuh terlindung dari infeksi kronik HPV yang dapat berkembang menjadi kanker serviks. ${ }^{6}$

Vaksin perlu diberikan sebelum terjadi infeksi dan hal ini menjadi sangat penting terutama di negara-negara berkembang yang belum memiliki program skrining nasional untuk menentukan kanker serviks itu secara rutin. ${ }^{7}$ Saat ini terdapat dua produk vaksin yang beredar yaitu vaksin bivalen dan vaksin kueadrivalen. ${ }^{8}$ Vaksin bivalen berisikan fragmen L1 dari dua HPV genotipe high risk yang tersering menginfeksi serviks yaitu HPV-16 dan HPV-18. Vaksin kuadrivalen berisikan fragmen L1 dari HPV-16 dan HPV-18, ditambah dengan HPV tipe low risk yang paling sering menyebabkan genital wrats yaitu HPV-6 dan HPV-11. Sayangnya, sampai sekarang belum ada vaksin yang dapat mencegah infeksi seluruh tipe HPV karena belum ditemukan reaksi silang pada major capsid protein L1 di antara genotipe HPV.

Perbedaan variasi genetik yang mengkode protein L1 HPV-16 perlu dipelajari oleh karena gambaran variasi genetik L1 ditemukan berbeda dari suatu daerah dengan daerah yang lainnya. Sebagai contoh, variasi genetik $L 1 H P V-16$ dari Asia ${ }^{9,10}$ berbeda dengan HPV dari belahan bumi yang lain di Eropa, ${ }^{11,12}$ dan Amerika. ${ }^{13}$ Penelitian mengenai sekuens gen $L 1$ masih sangat terbatas di Indonesia. Studi mengenai variasi sekuens gen $L 1 \mathrm{HPV}-16$ sangat diperlukan karena dapat memberikan informasi yang amat berguna, salah satunya untuk pengembangan vaksin, terlebih oleh karena HPV-16 merupakan genotipe yang paling sering menginfeksi pada pasien kanker serviks. Tujuan penelitian ini untuk menganalisis sekuens gen $L 1 H P V-16$ yang berasal dari Kota Bandung, Indonesia dan kemudian mengisolasi gen tersebut. Hasil isolasi $L 1 H P V-16$ selanjutnya diharapkan dapat dipergunakan sebagai sumber antigen untuk mendesain vaksin HPV rekombinan menggunakan teknologi viral-like particles.

\section{Metode}

Desain studi ini adalah desain deskriptif yang menganalisis deoxyribonucleic acid (DNA) virus dari biopsi pasien kanker serviks yang diambil dari bulan Juni sampai Oktober 2010 di Departemen Kebidanan dan Kandungan Rumah Sakit Dr. Hasan Sadikin Bandung. Hanya sampel hasil isolasi DNA genomik dengan konsentrasi yang baik yang diikutsertakan dalam proses pengklonan. Pengambilan sampel biopsi telah mendapatkan informed consent dari pasien dan persetujuan etik untuk penelitian ini diberikan 
oleh Komite Etik Penelitian Kesehatan (Health Research Ethics Committee) Fakultas Kedokteran Universitas Padjajaran/RSHS Bandung No. 190/ FKUP-RSHS/KEPK/Kep./EC/2010.

Jaringan biopsi yang mengandung deoxyribonucleic acid (DNA) manusia dan juga DNA HPV diisolasi dengan cara menggunakan kit komersial (QIAmp DNA mini kit, Qiagen, Jerman). Secara singkat, dilakukan penggerusan jaringan biopsi secara mekanis dengan menggunakan nitrogen cair, mortar, dan pestle untuk memudahkan proses lisis sel. Kualitas DNA diuji dengan cara elektroforesis DNA dalam gel agarose $0,8 \%$, sedangkan secara kuantitatif DNA genomik diuji dengan spektrofotometer. Kemudian dilakukan pemeriksaan genotipe HPV dengan menggunakan kit komersial Linear Array HPV Genotyping Test (Roche, Branchburg USA) untuk mengonfirmasi infeksi HPV-16.

Pada sediaan deoxyribonucleic acid (DNA) dilakukan reaksi amplifikasi DNA dengan enzim Hotstart DNA polimerase menggunakan primer konsensus HPV (SPF10) yang mengenali daerah lestari pada gen $L 1 H P V(65 \mathrm{pb})$. Pada penelitian ini digunakan beberapa pasang primer yakni pasangan primer spesifik gen $\beta$-globin manusia (RS40/RS42) yang merupakan internal kontrol DNA manusia pada sediaan dan pasangan primer konsensus HPV (SPF10F/R) dengan reaksi PCR sebagai berikut: inisiasi denaturasi pada suhu 95 ${ }^{0} \mathrm{C}$ selama 2 menit; dilanjutkan dengan denaturasi $95^{\circ} \mathrm{C}$ selama 30 detik, annealing $40-49^{\circ} \mathrm{C}$ selama 30 detik, elongasi $72{ }^{\circ} \mathrm{C}$ selama 30 detik sebanyak 25 siklus; dan diakhiri oleh tahap elongasi akhir $72{ }^{\circ} \mathrm{C}$ selama 5 menit.

Untuk dapat mengenali daerah L1 HPV-16 digunakan primer L1-16F/R (1 pmol) dan enzim $0,25 \mathrm{U}$ DreamTaq DNA polimerase (Fermentas) dengan reaksi polymerase chain reaction (PCR) sebagai berikut: inisiasi denaturasi pada suhu $95^{\circ} \mathrm{C}$ selama 2 menit; dilanjutkan dengan tahap denaturasi $95{ }^{\circ} \mathrm{C}$ selama 30 detik, annealing $52.4{ }^{\circ} \mathrm{C}$ selama 40 detik, elongasi $72{ }^{\circ} \mathrm{C}$ selama 1 menit 40 detik sebanyak 30 siklus; dan diakhiri oleh tahap elongasi akhir $72{ }^{\circ} \mathrm{C}$ selama 5 menit.

Gen utuh $L 1$ HPV-16 ( 1,6 kb) diamplifikasi dengan enzim $P f u$ DNA polimerase (high fidelity) kemudian dikloning ke dalam vektor kloning pJET1.2 (Fermentas). Klon rekombinan yang mengandung insert gen $L 1 H P V-16$ diverifikasi lebih lanjut dengan enzim restriksi dan PCR menggunakan primer spesifik gen L1 HPV-16. Kemudian fragmen DNA L1 HPV-16 dipurifikasi dari gel agarose 1,2\% menggunakan Gel/PCRDNA fragment extraction Kit (Geneaid), yang selanjutnya tiap-tiap fragmen DNA L1 HPV16 diligasikan ke vektor pJET1.2 (Fermentas) dengan metode blunt cloning menggunakan enzim
T4 ligase. Suspensi reaksi ligasi ditransformasikan ke dalam sel T10 kompeten menggunakan metode kejutan panas- $\mathrm{CaCl}_{2}$ dan ditumbuhkan pada plat agar LB yang mengandung $100 \mathrm{ug} / \mathrm{mL}$ ampisilin. Selanjutnya, dari setiap plasmid rekombinan pJET1.2-L1 HPV-16 dipilih tiga koloni untuk ditumbuhkan pada LB cair. Plasmid rekombinan diisolasi dengan metode alkali-lisis menggunakan plasmid extraction kit (Fermentas). Hasil isolasi tersebut dianalisis pada gel agarose $0,8 \%$. Insert fragmen DNA L1 HPV-16 pada klon rekombinan pJET1.2-L1 HPV-16 dikonfirmasi dengan reaksi PCR menggunakan pasangan primer yang sama dan dikonfirmasi dengan enzim restriksi BamHI dan $B g I I I$ (NEB).

Urutan nukleotida gen L1 HPV-16 dari klon rekombinan representatif disekuensing dengan Metode Sanger. Informasi nukleotida gen L1 yang diperoleh pada penelitian ini lalu dianalisis lebih lanjut menggunakan program GENEIOUS dengan membandingkan data sekuens gen L1 $H P V$ dari GenBank dan Los Alamos National Laboratory. Verifikasi DNA klon rekombinan pJET1.2-L1/16 dari sampel 1, 2, 3, dan 5 dilakukan dengan teknik sekuensing dan dianalisis lebih lanjut dengan software BIOEDIT dan Basic Local Alignment Search Tool (BLAST N) dari http:// www.ncbi.nlm.nih.gov. Software tersebut dapat membandingkan sekuens yang diperoleh dan mencari kecocokan antara sekuens yang diteliti dan sekuens referensi dari database GenBank. Perbedaan urutan sekuen nukleotida dan asam amino klon sampel isolat Bandung dibandingkan dengan sekuen GenBank dari Thailand sebagai referensi yang diambil dari data GenBank.

\section{Hasil}

Dari kumpulan sampel jaringan biopsi penelitian yang termasuk dalam Working Group Onkologi Unit Penelitian Kesehatan Fakultas Kedokteran Universitas Padjajaran, diambil 7 (tujuh) sampel untuk diperlakukan isolasi DNA genomik HPV. Sampel hasil dari isolasi DNA genomik dengan konsentrasi yang kurang tidak diikutsertakan dalam proses pengklonan. Hasil amplifikasi DNA genomik mempergunakan primer housekeeping genes $(408 \mathrm{pb})$ dan primer konsensus $(451 \mathrm{pb})$ memperlihatkan bahwa primer pilihan tersebut berjalan telah sesuai, dan amplifikasi gen $L 1 H P V$ $16(1595 \mathrm{pb})$ menggunakan enzim DreamTag DNA polimerase menghasilkan produk spesifik (Gambar 1). Dengan menggunakan kit komersial Linear Array HPV Genotyping Test (Roche, Branchburg USA) infeksi HPV-16 pada sediaan jaringan biopsi dapat dikonfirmasi (Gambar 2).

Karena tidak didapatkan produk amplifikasi 


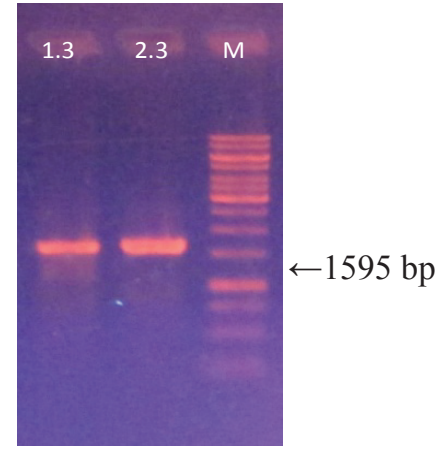

Gambar 1 Elektroforegram Hasil Isolasi DNA L1 HPV-16 yang Divisualisasikan pada Gel Agarose 1,2\% Menunjukkan Pita sebesar 1595 bp pada Sampel No. 1.3 dan 2.3 (M=marker)

yang memuaskan hanya dua dari tujuh sampel yang akhirnya dapat dilakukan kloning. Kloning amplikon L1 HPV-16 diperlakukan ke vektor pJET1.2, kemudian klon rekombinan dikonfirmasi dengan reaksi PCR dan enzim restriksi. Konfirmasi klon rekombinan pJET1.2/L1-16 dengan teknik PCR menggunakan primer spesifik gen L $1 \mathrm{HPV}-16$ menghasilkan fragmen DNA yang sesuai dengan yang diharapkan yaitu $\sim 1.600$ pb (Gambar 3).

Restriksi dilakukan dengan mempergunakan enzim BamHI. Hasil restriksi pada gel agarose $0,8 \%$ nilainya sebesar 4.569 pb juga dengan enzim restriksi BgIII yang akan memotong plasmid di dua sisi sehingga menghasilkan fragmen DNA sebesar 2.974 pb dan 1.595 pb (Gambar 2).

Setelah dibandingkan dengan sekuens pada

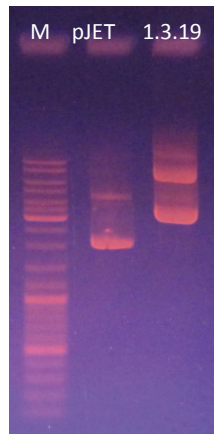

Gambar 3 Elektroforegram Hasil Isolasi Plasmid Rekombinan pJET1.2/L1-16 dari Sampel No. 1.3 (M=marker)

GenBank dari Thailand sebagai referensi yang diambil dari data GenBank, hasil klon yang disekuens menunjukkan bahwa klon sampel 1 dan 2 memiliki kesamaan 97\% dan 99\% dengan sekuens nomor akses FJ61050.1 yaitu isolat yang berasal dari Thailand. Prediksi asam amino dari klon sampel 1 menunjukkan bahwa nukleotida dari klon sampel 1 menghasilkan 531 asam amino. Pada sekuens nukleotida klon sampel isolat dari Bandung terlihat beberapa perbedaan dibandingkan dengan sekuens nukleotida pada GenBank yang berasal dari isolat Thailand yang menyebabkan perubahan asam amino (Tabel 1).

Kecuali pada mutasi di urutan 1266 , perbedaan sekuens nukleotida pada klon sampel 1 tersebut mengakibatkan perubahan asam amino. Beberapa kemungkinan sebagai penyebab perbedaan pada

\section{LINEAR ARRAY HPV Genotyping Test}

Reference Guide/ Referenzleitfaden/ Guide de références/ Guide di riferimento/ Guía de referencia/ Guia de Referência/ Referenceguide/ Referensguide

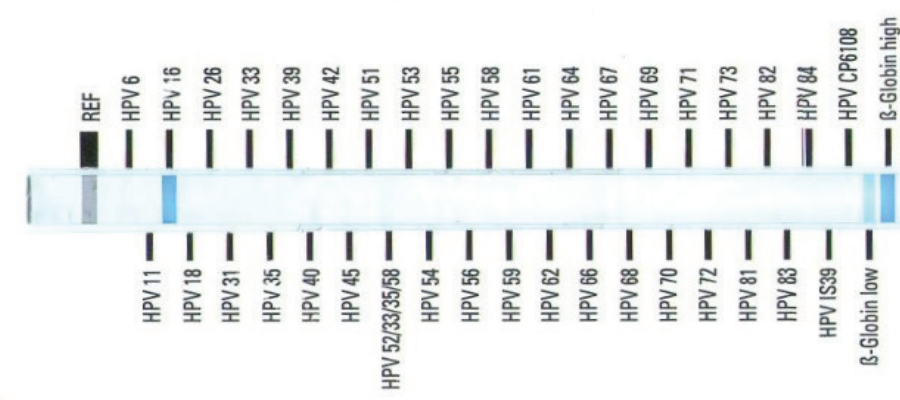

Roche Molecular Systems, Inc.

$04392724041-02$

Gambar 2 Infeksi HPV-16 Dikonfirmasi dengan Kit Diagnostik Komersial Linear Array HPV Genotyping Test (Roche, Branchburg USA) 
Tabel 1 Perbedaan Urutan Sekuens Nukleotida dan Asam Amino Isolat Bandung Klon Sampel 1 Dibandingkan dengan Sekuens GenBank Isolat Thailand (FJ610150.1)

\begin{tabular}{cclll}
\hline Urutan & Basa Nukleotida & & \multicolumn{2}{c}{ Asam Amino } \\
\hline 103 & $\mathrm{G} \rightarrow \mathrm{A}$ & $\mathrm{A}$ (Alanin) & $\rightarrow$ & $\mathrm{T}$ (Treonin) \\
398 & $\mathrm{~T} \rightarrow \mathrm{C}$ & $\mathrm{V}$ (Valin) & $\rightarrow$ & $\mathrm{A}$ (Alanin) \\
576 & $\mathrm{G} \rightarrow \mathrm{A}$ & $\mathrm{E}$ (Asam glutamat) & $\rightarrow$ & $\mathrm{K}$ (Lisin) \\
620 & $\mathrm{C} \rightarrow \mathrm{A}$ & $\mathrm{T}$ (Treonin) & $\rightarrow$ & $\mathrm{N}$ (Aspargin) \\
704 & $\mathrm{~A} \rightarrow \mathrm{G}$ & $\mathrm{D}$ (Asam aspartat) & $\rightarrow$ & $\mathrm{G}$ (Glisin) \\
1266 & $\mathrm{~T} \rightarrow \mathrm{C}$ & $\mathrm{S}$ (Serin) & $\rightarrow$ & $\mathrm{S}$ (Serin) \\
1530 & $\mathrm{~A} \rightarrow \mathrm{C}$ & $\mathrm{K}$ (Lisin) & $\rightarrow$ & $\mathrm{N}$ (Aspargin) \\
\hline
\end{tabular}

sekuens nukleotida tersebut di antaranya mutasi pada saat amplikon DNA sampel 1 oleh enzim DreamTaq DNA polimerase yang dipergunakan pada penelitian ini tidak mempunyai aktivitas proof reading. Sejauh ini belum didapatkan data sekuens nukleotida isolat Bandung yang menjadi rujukan pada GenBank, sehingga kemungkinan urutan sekuens nukleotida dari isolat Bandung (sampel 1) memang memiliki perbedaan dengan urutan nukleotida isolat Thailand.

Demikian juga dengan sampel 2 yang memiliki kesamaan 99\% dengan sekuens isolat Thailand (FJ610150.1). Prediksi asam amino dari klon sampel 2 memperlihatkan bahwa nukleotida dari klon sampel 2 menghasilkan 531 asam amino. Sama seperti sampel 1, sampel 2 juga memiliki perbedaan yang menyebabkan perubahan asam amino (Tabel 2). Berdasarkan hasil penjajaran dengan sekuens yang terdapat pada GenBank, terlihat 4 asam amino yang berbeda.

\section{Pembahasan}

Vaksin pada human papilloma virus (HPV)

Tabel 2 Perbedaan Urutan Sekuens Nukleotida dan Asam Amino Isolat

Bandung Klon Sampel 2

Dibandingkan dengan Sekuens

GenBank Isolat Thailand (FJ610150.1)

\begin{tabular}{ccccc}
\hline Urutan & $\begin{array}{c}\text { Basa } \\
\text { Nukleotida }\end{array}$ & \multicolumn{3}{c}{ Asam Amino } \\
\hline 365 & $\mathrm{~T} \rightarrow \mathrm{C}$ & $\begin{array}{c}\mathrm{S} \\
(\text { Serin) }\end{array}$ & $\rightarrow$ & $\begin{array}{c}\mathrm{P} \\
(\text { Prolin) }\end{array}$ \\
1129 & $\mathrm{~T} \rightarrow \mathrm{G}$ & $\begin{array}{c}\mathrm{A} \\
(\text { Serin) }\end{array}$ & $\rightarrow$ & $\begin{array}{c}\mathrm{T} \\
\text { (Alanin) }\end{array}$ \\
1268 & $\mathrm{~T} \rightarrow \mathrm{C}$ & $\begin{array}{c}\mathrm{S} \\
(\text { Serin) }\end{array}$ & $\rightarrow$ & $\begin{array}{c}\mathrm{P} \\
(\text { Prolin) }\end{array}$ \\
\hline
\end{tabular}

mengandung virus like particle (VLP) L1 dan sudah beredar di lebih 100 negara. Walaupun demikian, vaksin hanya mampu melindungi 15 tipe high risk HPV yang memiliki kesamaan homologi dengan HPV-16 dan HPV-18. ${ }^{7}$ Virus HPV-16 dan HPV-18 merupakan HPV tipe tersering (70-80\%) yang menginfeksi jaringan serviks. ${ }^{1}$ Virus HPV-16 dan HPV-18 ini dapat menginfeksi jaringan serviks dengan infeksi satu genotipe atau beberapa genotipe sekaligus. ${ }^{14}$

Genom HPV terdiri atas protein E (early protein) dan protein L (late protein). Protein E (E1, E2, E4, E5, E6, E7) bersifat onkogenik, sedangkan protein L (L1 dan juga L2) dapat membentuk kapsid yang bersifat imunogenik. ${ }^{4}$ Berdasarkan pada potensi onkogeniknya, HPV dibedakan menjadi tipe low risk dan high-risk. ${ }^{4}$ HPV tipe low risk misalnya HPV-6, -11, -42, -43, dan -44 terutama berhubungan dengan genital warts. HPV tipe high risk misalnya HPV-16, -18, $-31,-33,-39,-45,-51,-52,-56,-58,-59$, dan -68 merupakan agen etiologi yang berhubungan dengan kanker serviks. ${ }^{7}$ Dari hasil skrining sitologi normal dapat ditemukan juga infeksi genotipe high risk HPV-16 dan HPV-18. ${ }^{1}$ Hal ini disebabkan karena infeksi virus HPV adalah infeksi yang self limited dan hanya infeksi yang kronik yang dapat berkembang menjadi kanker serviks. ${ }^{15}$ Munculnya banyak kasus akibat infeksi HPV memerlukan metode pencegahan infeksi HPV melalui vaksinansi. ${ }^{5}$

Vaksin yang ada di pasaran saat ini memakai teknologi VLP dari komponen yang serupa dengan gen $L 1$ virus, yaitu suatu late protein yang terdapat pada kapsid protein. Genom HPV diselubungi oleh non-enveloped, icosahedral capsid yang terdiri atas 72 pentamer protein kapsid mayor L1 dan sejumlah protein kapsid minor L2. ${ }^{4,16}$ Kapsid protein adalah bagian luar virus yang berfungsi melindungi materi genetik di dalamnya. Kapsid tersusun atas sejumlah unit protein L1 dan L2 yang disebut kapsomer yang merupakan struktur kapsid protein. ${ }^{16}$ Dengan teknologi VLP telah dihasilkan partikel yang 
sangat mirip dengan partikel HPV asli yang dapat menginduksi antibodi netralisasi virus. Sistem imun dapat mengenali VLP sebagai infeksi virus dan meresponsnya walaupun VLP berinti kosong dan tidak mengandung DNA virus. Dengan demikian, VLP tidak dapat menyebabkan infeksi. ${ }^{17}$

Berdasarkan hasil deteksi dengan memakai kit komersial linear array HPV genotyping test (Roche, Branchburg USA), sampel biopsi yang diambil dari jaringan kanker serviks mengandung DNA manusia dan DNA HPV yang menginfeksinya yaitu HPV-16 (Gambar 2). Pita DNA pengkode gen $L 1$ berhasil didapatkan dengan metode polymerase chain reaction (PCR) menggunakan primer spesifik HPV-16 berukuran 1.595 pb. Rekombinan DNA L1 HPV-16 menunjukkan kesamaan dengan L1 HPV-16 isolat dari Thailand dan hal ini mengonfirmasi bahwa gen $L 1$ DNA berhasil diinsersi. Tampak dari hasil analisis asam amino kedua isolat asal Bandung terdapat variasi-variasi yang menunjukkan variasi intratipe. Variasi protein L1 dapat menyebabkan varian-varian baru yang lebih spesifik terhadap suatu virus.

Ekspresi kapsid L1 dari 6 strain HPV-16 yang berbeda dari 5 negara di Aljazair, Senegal, Filipina, Jerman, dan Thailand menghasilkan pembentukan VLP untuk semua jenis strain yang diteliti dan hasil yang diperoleh menunjukkan variasi VLP yang bergantung pada urutan gen L1. ${ }^{17}$ Penelitian yang dilakukan di Indonesia sebelumnya di Jakarta menggambarkan variasi L1 HPV-16 yang spesifik untuk etnik Jawa, yaitu mutasi pada $6826 \mathrm{~T} \mathrm{L1}$ pada $73 \%$ isolatnya. ${ }^{18}$ Hal ini membuktikan variasi yang berbeda yang mungkin spesifik untuk etnik tertentu. Pada kedua isolat Bandung ini tidak ditemukan variasi Jawa tersebut, yang dimungkinkan karena keterbatasan jumlah sampel yang diperiksa. Selain mencari subtipe pada L1, penelitian bidang vaksin juga mulai banyak mengarah pencarian komponen baru. Kapsid minor L2 telah mulai banyak diteliti perannya dalam pengembangan vaksin $\mathrm{HPV},{ }^{19}$ sehingga penelitian dalam upaya mendeteksi variasi kapsid minor L2 saat ini mulai banyak dilakukan.

Penelitian ini memiliki keterbatasan, belum dilakukan studi imunoinformatika pada fragmen L1 HPV-16 darivarianyang baru untuk mengetahui lebih dalam lagi sifat imunogenesitasnya. Sifat imunogenesitas dapat berkurang dengan variasi yang timbul pada berbagai intratipe HPV-16. ${ }^{20}$

Simpulan, pada penelitian ini telah berhasil mengisolasi fragmen L1 HPV-16 yang homolog dengan isolat referensi dari Thailand. Penelitian ini sudah membuat kloning gen L1 HPV-16 tersebut, dan diharapkan kloning L1 HPV-16 dari hasil penelitian ini dapat dipergunakan sebagai sumber antigen di dalam pengembangan vaksin yang spesifik untuk populasi Indonesia.

\section{Ucapan Terima Kasih}

Sebagai apresiasi kami mengucapkan terima kasih kepada Octavia Ramayanti yang telah membantu untuk menggulirkan ide penelitian ini dan mendapatkan bantuan dana Kementerian Pendidikan Nasional melalui Hibah Strategis Nasional 2010. Penelitian ini merupakan bagian dari penelitian payung yang dikelola Working Group Onkologi Fakultas Kedokteran Universitas Padjadjaran Bandung. Kepada anggota working group onkologi, terutama Maringan DL Tobing, dr., SpOG dan Dr. Ani Melani Maskoen, drg., M.Kes dan Bethy Hernowo, dr., $\operatorname{SpPA}(\mathrm{K}), \mathrm{PhD}$, kami ucapkan terima kasih atas bantuannya dalam penyelenggaraan penelitian ini.

\section{Daftar Pustaka}

1. Clifford GM, Gallus S, Herrero R, Muñoz $\mathrm{N}$, Snijders PJ, Vaccarella S, dkk. Worldwide distribution of human papillomavirus types in cytologically normal women in the International Agency for Research on Cancer HPV prevalence surveys: a pooled analysis. Lancet. 2005;366(9490):991-8.

2. Leyden WA, Manos MM, Geiger AM, Weinmann S, Mouchawar J, Bischoff K, dkk. Cervical cancer in women with comprehensive health care access:attributable factors in the screening process. J Natl Cancer Inst. 2005;97(9):675-83.

3. Aziz MF. Gynecological cancer in Indonesia. J Gynecol Oncol. 2009;20(1):8-10.

4. Bosch FX, Castellsagué $\mathrm{X}$, de Sanjosé S. HPV and cervical cancer, screening or vaccination? Br J Cancer. 2008;98(1):15-21.

5. de Villiers EM, Fauquet C, Broker TR, Bernard HU, zur Hausen H. Classification of papillomaviruses. Virology. 2004;324:17-27.

6. Bishop B, Dasgupta J, Klein M, Garcea RL, Christensen ND, Zhao R, dkk. Crystal structures of four types of human papillomavirus L1 capsid proteins: understanding the specificity of neutralizing monoclonal antibodies. J Biol Chem. 2007; 282:31803-11.

7. Kane MA, Serrano B, de Sanjosé S, Wittet S. Implementation of human papillomavirus immunization in the developing world. Vaccine. 2012;30 Suppl 5:F192-200.

8. Jit M, Chapman R, Hughes O, Choi YH. 
Comparing bivalent and quadrivalent human papillomavirus vaccines: economic evaluation based on transmission model. BMJ. 2011;27;(343):d5775.

9. Yue Y, Yang H, Wu K, Yang L, Chen J, Huang $\mathrm{X}$, dkk. Genetic variability in L1 and L2 genes of HPV-16 and HPV-58 in Southwest China. PLoS ONE. 2013;8(1):e55204.

10. Pillai MR, Hariharan R, Babu JM, Lakshmi S, Chiplunkar SV, Patkar M, dkk. Molecular variants of HPV-16 associated with cervical cancer in Indian population. Int J Cancer. 2009;125(1):91-103.

11. Ntova CK, Kottaridi C, Chranioti A, Spathis A, Kassanos D, Paraskevaidis E, dkk. Genetic variability and phylogeny of high risk HPV type 16, 18, 31,33 and 45 L1 gene in Greek women. Int J Mol Sci. 2012;13(1):117.

12. Cento V, Ciccozzi M, Ronga L, Perno CF, Ciotti M. Genetic diversity of human papillomavirus type 16 E6, E7, and L1 genes in Italian women with different grades of cervical lesions. J Med Virol. 2009;81(9):1627-34.

13. Castro MM, Farias IP, Borborema-Santos CM, Correia G, Astolfi-Filho S. Prevalence of human papillomavirus (HPV) type 16 variants and rare HPV types in the central Amazon region. Genet Mol Res. 2011;10(1):186-96.
14. Tota JE, Chevarie-Davis M, Richardson LA, Devries M, Franco EL. Epidemiology and burden of HPV infection and related diseases: implicationsfor prevention strategies. Prev Med. 2011;53: S12-21.

15. Schiffman M, Castle PE, Jeronimo J, Rodriguez AC, Wacholder S. Human papillomavirus and cervical cancer. Lancet. 2007;370(9590):890-907.

16. Ishii Y, Ozaki S, Tanaka K, Kanda T. Human papillomavirus 16 minor capsid protein L2 helps capsomeres assemble independently of intercapsomeric disulfide bonding. Virus Genes. 2005;31(3):321-8.

17. Abdoli A, Soleimanjahi H, Fotouhi F, Teimoori A, Pour Beiranvand S, Kianmehr Z. Human papillomavirus type16L1 VLP production in insect cells. Iran $\mathrm{J}$ Basic Med Sci. 2013;16(8):891-5.

18. de Boer MA, Peters LA, Aziz MF, Siregar B, Cornain S, Vrede MA, dkk. Human papillomavirus type 16 E6, E7, and L1 variants in cervical cancer in Indonesia, Suriname, and The Netherlands. Gynecol Oncol. 2004;94(2):488-94.

19. Jagu S, Kwak K, Karanam B, Huh WK, Damotharan V, Chivukula SV, dkk. Optimization of multimeric human papillomavirus L2 vaccines. PLoS One. 2013;8(1):e55538. 